\title{
CAPTURING TEACHING MOTIVATION OF TEACHER IN THE DISADVANTAGED AREAS
}

\author{
Hanggara Budi Utomo*, Dewi Retno Suminar, Hamidah \\ Universitas Airlangga, Indonesia \\ *e-mail: hanggara.budi.utomo-2014@psikologi.unair.ac.id
}

\begin{abstract}
Teaching motivation of teachers is very important for student's development. The purpose of this study is to test the teaching motivation of teachers in disadvantaged areas affected by the school climate and self-concept through the satisfaction of basic psychological needs. The subjects of this research were 241 teachers. Data collection techniques used instruments in the form of a school climate scale, a scale of self-concept, a scale of basic psychological need satisfaction, and a scale of teaching motivation. The data analysis techniques used a structural equation modeling. The results showed that the attention of teachers who teach in disadvantaged areas shows that the school climate and teacher's selfconcept differently provide an important role in teaching motivation mediated by the basic psychological needs satisfaction. This means that teaching motivation is a result of the role of the school climate as an external factor and satisfaction of basic psychological needs and self-concept as an internal factor. The implication of this research is the need for programs to develop teacher motivation in disadvantaged areas by optimizing and considering school climate, self-concept, and satisfaction of basic psychological needs as influential factors.
\end{abstract}

Keywords: school climate, self concept, teaching motivation, basic psychological need satisfaction, teacher

\section{MEMOTRET MOTIVASI MENGAJAR GURU DI DAERAH TERTINGGAL}

\begin{abstract}
Abstrak: Motivasi mengajar guru merupakan hal yang sangat penting bagi perkembangan siswa. Tujuan penelitian ini adalah menguji motivasi mengajar guru di daerah tertinggal yang dipengaruhi oleh iklim sekolah dan konsep diri melalui kepuasan kebutuhan dasar psikologis. Subjek penelitan ini adalah guru berjumlah 241 guru. Teknik pengumpulan data menggunakan instrumen berupa skala iklim sekolah, skala konsep diri, skala kepuasan kebutuhan dasar psikologis, dan skala motivasi mengajar. Teknik analisis data menggunakan model persamaan struktural. Hasil penelitian ini adalah perhatian terhadap guru yang mengajar di daerah tertinggal menunjukkan bahwa iklim sekolah dan konsep diri guru secara berbeda memberikan peran penting pada motivasi mengajar yang dimediasi oleh kepuasan kebutuhan dasar psikologis. Hal itu berarti bahwa motivasi mengajar merupakan hasil dari peran dari iklim sekolah sebagai faktor eksternal dan kepuasan kebutuhan dasar psikologis serta konsep diri sebagai faktor internal. Implikasi penelitian ini adalah perlu adanya program-program pengembangan motivasi guru di daerah tertinggal dengan mengoptimalkan dan mempertimbangkan iklim sekolah, konsep diri, dan kepuasan kebutuhan dasar psikologis sebagai faktor yang berpengaruh.
\end{abstract}

Kata Kunci: iklim sekolah, konsep diri, kepuasan kebutuhan dasar psikologis, motivasi mengajar, guru

\section{INTRODUCTION}

One of the conditions experienced by disadvantaged areas is that the quality of human resources is relatively lower than the national average due to limited community access to education, health and employment; limited access to capital; there are security disturbances and disasters; remote indigenous community; previous development policies. In connection with the limited access of the community to education, a program to provide educational facilities and infrastructure is needed, as well as the provision of educational staff qualifications in disadvantaged areas. The program of providing educational staff qualifications in disadvantaged areas requires the role of teachers 
in schools, given the role of teachers who directly touch, know the conditions, what problems and problem solving are used in helping to overcome the things experienced in the school environment (Dirjen Cipta Karya, 2012).

The government through the Ministry of Education and Culture places great hopes on teachers who are devoted to teaching in special areas, especially in the frontier, outermost, and disadvantaged (3T) regions. According to Minister of Education and Culture Regulation No. 34 of 2012, special areas are areas that are remote or underdeveloped with the conditions of remote indigenous peoples; areas with borders of other countries; areas that have experienced natural disasters, social disasters, or areas that are in a state of emergency; outer small island. But in reality, being a teacher in a special area often has its own problems and challenges. The Indonesian government then made a policy to overcome the problem of lack of attention to adequate educational facilities and resources in disadvantagedareas. Governmentpolicy is known as Guru Garis Depan (Frontline Teacher). Guru Garis Depan (Frontline Teacher) is a government affirmation to realize equitable quality education services in Indonesia, especially in remote, outermost, and disadvantaged areas (3T). The existence of this program, makes the willingness of the community to become teachers in remote, outermost, and disadvantaged areas is quite high.

Based on data from the Ministry of Education and Culture's bureau of communication and public service center, that in 2015 the number of teachers who served in four provinces in the 3T area category was 795 people; in 2016 it increased to 6,296 people assigned to $3 \mathrm{~T}$ areas spread across 14 provinces and 93 districts; and in the 2018 period the Government through the Ministry of Education and Culture plans to recruit 17,000 frontline teacher candidates to be assigned to the $3 \mathrm{~T}$ regions (Putri, Destio, \& Rahmayanti, 2017). Teachers sent through this frontline teacher program must be prepared to teach and be placed anywhere. However, it is not easy to become a frontline teacher because there are various stringent requirements and selections if you want to be a frontline teacher. One of them is willing to be placed in one of the places in the 3T area in Indonesia for at least 10 years or in accordance with the provisions in each region (Putri, et. al., 2017).
The policy carried out by the Government seems to be not running optimally considering that teachers are rather difficult to place in remote, outermost, and disadvantaged areas. Likewise, the difficulty of establishing standard educational facilities due to communication difficulties, and the difficulty in finding teaching aids (Sofiah, 2016). In addition, the lack of coordination between the central and regional governments makes the frontline teacher program still not optimal. This resulted in the teachers resigning from the program because the teacher did not know the state of the assigned area.

The information above is in accordance with the study conducted by Berg, that most teachers are reluctant to teach in remote and disadvantaged areas due to the location of schools that are difficult to reach. In general, teachers who teach in remote or disadvantaged areas feel inconvenience due to inadequate facilities, far from the center of the crowd, and the government does not guarantee the facilities where the teacher lives. The result is that many teachers who were previously in disadvantaged or remote areas feel uncomfortable, and propose to move schools in urban areas (Paramitha, 2012). In line with the study, the findings of research conducted by Hartini (2012) stated that less than the maximum number of teachers teaching in disadvantaged areas was due to the high level of difficulty in geographical conditions, lack of access to transportation and communication, and lack of facilities and infrastructure for learning activities. This certainly has an impact on teacher absence from school, which is disrupted learning processes and teacher resistance to teaching responsibilities is reduced, so that has an impact on teacher motivation to teach (Abeles, 2013).

Based on Education Sector Analytical and Capacity Development Partnership data in 2014, the absence rate of elementary school teachers in remote areas reached 20 percent (McKenzie, Nugroho, Ozolins, McMillam, \& Sumarto, 2014). The highest teacher absence rates are in Sumatra, namely 17.4 percent, Java by 13.4 percent, Kalimantan by 11.4 percent, while Bali and Nusa Tenggara are 12.5 percent. As many as 25 percent of teachers in Sumatra and Kalimantan said they did not teach because they were late. While in Sulawesi, Bali and Nusa Tenggara, 22 
percent of teachers reasoned not to teach for personal reasons. In fact, the Government has allocated 50 percent of the education fund for teacher salaries and allowances. The impact of teacher absenteeism in the classroom will affect the quality of teaching and changes in classroom activities (McKenzie, et. al., 2014). Apart from that, elementary and junior high school teachers who teach in small villages scattered throughout Indonesia, generally when entering into classrooms only teach from books, without making plans to implement learning. This makes the education observer give a statement that the condition of teachers who lack enthusiasm in teaching is caused by the ignorance of the teachers in preparing plans for implementing better learning (Sofiah, 2006).

The phenomenon of the problems that have been described above is very much different from education in the contemporary period which places more emphasis on quality teaching. The quality of the teacher in education greatly determines how effective and efficient the teaching and learning process organized by the teacher. Therefore, attention needs to be paid to teacher motivation to ensure quality teaching (Salifu \& Agbenyega, 2013). Teacher motivation refers to behavior when teaching in class, because it can create a conducive teaching and learning atmosphere. Teaching motivation refers to the teacher's thoughts and feelings about himself to be involved in teaching activities (Roth, Assor, Kanat-Maymon, \& Kaplan, 2007).

Supporting the teacher's motivational teaching behavior in schools shows that the teacher chooses a profession for teaching consisting of various things, including: (a) intrinsic considerations relating to the teacher's role activities; (b) extrinsic considerations relating to aspects in teaching; and (c) altruistic considerations relating to perceptions of teaching as a profession socially respected and contributing to society. These three things are the embodiment of the implementation of the motivation to teach teachers in schools (Richardson, Watt, \& Karabenick, 2014; Mansfield, Wosnitza, \& Beltman, 2012).

Based on the statement above, to develop the motivation to teach teachers in disadvantaged areas, it is necessary to investigate the contributing factors. According to Ryan
\& Deci (2000b), the emergence of motivation occurs because of internal and external support. Despite the internal and external support of the individual, but in reality some individuals have high motivation and some others show amotivation which is seen as low motivation in the individual (Ryan \& Deci, 2000b).

Internal factors that are thought to influence teaching motivation are related to satisfaction of basic psychological needs and self-concept. According to Gagne \& Deci (2005), basic psychological needs satisfaction is a nutriment for motivation development. Previous research findings state that basic psychological needs satisfaction is an interesting and exciting factor when a teacher teaches. This is supported by Reeve \& Su (2014) that the interests and desires and motivations of teachers to teach will emerge when there is an experience of psychological satisfaction of needs in terms of autonomy, competence, and relatedness while engaging in teaching activities and interacting with students. In addition to fulfilling basic psychological needs, self-concept can be a source of motivation when individuals are motivated to maintain and enhance self-internalization (Leonard, Beauvais, $\&$ Scholl, 1999). This is also supported by the study of Deci \& Ryan's study (1995) that the term self-competence is similar to self-concept, an important antecedent of motivation to be independent (autonomous motivation).

External factors that are thought to have an influence on teacher motivation to teach are related to school climate. School climate as an external factor has a strong influence on teacher motivation (Wei, 2012). A positive school climate as a source of motivation can motivate teachers to improve teaching competence in schools (Kocabas, 2009). Teachers who understand the importance of the school climate will have implications for education, namely teachers can develop characters who like to work hard and never give up (Werang, 2018). School climate is an important factor in job satisfaction, productivity, and teacher motivation, and plays a role in promoting student learning activities (Pretorius \& De Villiers, 2009).

Therefore, it is important to develop teacher motivation in disadvantaged areas by involving predictors of school climate, self-concept, and basic psychological needs satisfaction. 
This study aims to examine the role of teacher motivation in disadvantaged areas formed by the school climate and self-concept through satisfaction of basic psychological needs. In addition, first, we assume that the school climate influences teaching motivation (hypothesis 1). Second, self-concept influences teaching motivation (hypothesis 2). Third, school climate influences basic psychological needs satisfaction (hypothesis 3). Fourth, self-concept affects basic psychological needs satisfaction (hypothesis 4); Fifth, basic psychological needs satisfaction influences teaching motivation (hypothesis 5). Sixth, that the school climate influences teaching motivation by mediating basic psychological needs satisfaction (hypothesis 6). Finally, we hypothesize that self-concept influences teaching motivation by mediating basic psychological needs satisfaction (hypothesis 7).

\section{METHODS}

\section{Research Design and Participants}

This study uses a quantitative approach using survey research designs to examine the behavior of an individual or group. The survey research design was used because of the following considerations: (a) high representation; (b) low cost; (c) easy data collection; (d) good statistical significance; (e) subjectivity of small researchers; and (f) precis results (Werang, 2018). The population of this study is elementary school teachers who teach in areas with underdeveloped developmental status in East Java, while the sample of this study amounted to 241 teachers ( $25.31 \%$ male; $74.69 \%$ female) spread over four districts, namely Blitar, Kediri, Tulungagung, and Nganjuk Regency. The sampling technique uses multistage random sampling techniques with various random sampling methods that are used together effectively and efficiently.

\section{Instruments \\ School Climate}

The school climate in this study will be measured using an adaptation from the Organizational Climate Index (OCI) measuring instrument or the organization's climate index developed by Hoy, Smith, \& Sweetland (2002). The results of the development of the adaptation of The Organizational Climate Index measuring tools are 15 items, to measure four aspects of school climate, including: institutional vulnerability, collegial leadership, professional teacher behaviour, and achievement press. Each item has four response choices in the form of a Likert scale. Research participants were asked to respond to statements on the most appropriate response choices regarding aspects of the school climate with responses ranging from 1 (rarely occurs) to 4 (very frequently occurs), such as, "teachers in this school conduct professional assessments"; "students in this school are able to achieve the targets set for them"; "school principals uphold clear performance standards". The composite reliability coefficient value is .92 .

\section{Self-concept}

Teacher self-concept in this study was measured using adaptations from the Teacher Self-Concept Evaluation scale developed by Villa $\&$ Calvete (2001). The results of the development of the Teacher Self-Concept Evaluation scale adaptation of 17 items, to measure six aspects of self-concept, including: competence, interpersonal perception, satisfaction, risk taking and initiative, self-acceptance, and relationships with students. The item's score consists of six choices that move between "strongly disagree" to the statement "strongly agree". Each item is given a score, and then the score is calculated. Research participants were asked to respond to statements on response choices, such as: "it is easy for me to share and cooperate with others"; "I feel like a failure". The composite reliability coefficient value is .96 .

\section{Basic Psychological Needs Satisfaction}

Basic psychological needs satisfaction in this study will be measured using an adaptation of the Basic Psychological Need at Work scale developed by Ilardi (Gagne, 2003; Deci, Ryan, Gagne, Leone, Usunov, \& Kornazheva, 2001), which reveals the extent to which individuals experience satisfaction with three basic needs namely autonomy, relatedness, and competence. Autonomy refers to a sense of will and psychological freedom (example item: "I feel pressure at work"); relatedness refers to a feeling of belonging to others, and to care for and care for others (example item: "the people 
I work with don't seem to like me very much"); and competence involves feeling effective in individual actions or activities (example item: "when I work, I feel less able"). Study participants were asked to respond to statements on response choices from 1 (highly inappropriate) to 7 (very appropriate) for a favourable item, and from 1 (very appropriate) to 7 (very inappropriate) for an unfavorable item. The composite reliability coefficient value is .94 .

\section{Teaching Motivation}

Teaching motivation in this study will be measured through an adaptation of the autonomous motivation for teaching measuring tool developed by Roth, et. al. (2007) based on the conceptualization and initial measurement from Ryan \& Connell (1989). The results of the development of an autonomous motivation for teaching measuring instrument adaptation are 11 items, to measure four aspects of teaching motivation, including: external regulation (example item: "when I take the time to have a conversation with each student, I want to do it, because I want parents of students give appreciation to my knowledge and familiarity with their children "); regulation of introjection (example item: "when I work hard as a teacher, I want to do it because if I don't, I feel ashamed of myself"); identification regulations (example item: "when I work hard as a teacher, I want to do it because it is important for me to make students feel cared for"); and intrinsic regulation (example item: "when I take the time to have a conversation with each student, I want to do it because I like to hang out with children and teenagers"). Study participants were asked to respond to statements on response choices from 1 (very inappropriate) to 5 (very appropriate). The composite reliability coefficient value is .92 .

\section{Procedure for Translating Research Instruments}

Translation and adaptation procedures research instruments are researchers translating items in research instruments from English to Indonesian based on the Guidelines for Translating and Adapting Tests (Second Edition) from the International Test Commission (2017) as a guideline, with the following steps: (a) carry out licensing for the use and availability of original measuring instruments; (b) translating English-language items into Indonesian by two English-speaking people; (c) two people who have good Indonesian language skills but cannot speak English check whether the items in the questionnaire that have been translated in Indonesian are easy to understand; (d) Indonesian-language items are retranslated in English by two bilingual people who have never read the item before; (e) carry out the process of comparing and examining the results of English translation items with original English-language items; (f) five item readers, namely five people who work as primary school teachers check the readability of items in order to find out the layman's understanding of the statements of each item.

\section{Data Analysis}

This research used structural equation modeling (SEM) analysis technique with Amos of 21.0 version software, in seven main steps as follows: (a) model development based on concept and theory; (b) path Diagram development; (c) path diagram conversion to structural model; (d) determining input matrix and model estimation; (e) examining identification problem; (f) evaluating goodness of fit; and (g) interpreting and modifying the model (Setiyowati, Pali, Wiyono, \& Triyono, 2019).

\section{RESULT AND DISCUSSION \\ Result \\ Preliminary Analysis}

The statistical technique used to view participants' general descriptions and categorization of variable levels, namely descriptive analysis. Table 1 shows the results of a descriptive analysis of the general characteristics of study participants where most of the study participants were in the early adult age category with a percentage of nearly 35 percent with varied length of teaching. Table 2 shows the results of the descriptive analysis of each construct, where the level of school climate, self-concept, basic psychological need satisfaction, and teaching motivation in the medium category with a percentage above 60 percent. Summary descriptive analysis can be seen in Table 1 and Table 2. 
Table 1. The General Characteristics of Study Participants

\begin{tabular}{lccc}
\hline Characteristics & Subject Data (Years) & Frequency & Percentage (\%) \\
\hline Age & $22-30$ & 49 & 20.33 \\
& $31-40$ & 83 & 34.43 \\
& $41-50$ & 30 & 12.44 \\
& $51-60$ & 79 & 32.78 \\
Length of teaching & $2-15$ & 141 & 58.51 \\
& $16-30$ & 45 & 18.67 \\
& $31-40$ & 55 & 22.82 \\
\hline
\end{tabular}

Table 2. The Descriptive Analysis of Each Construct

\begin{tabular}{lcccc}
\hline Construct & Level & Score & Frequency & Percentage (\%) \\
\hline School climate & Low & $35-41$ & 58 & 24 \\
& Medium & $42-49$ & 147 & 61 \\
& High & $50-58$ & 35 & 15 \\
Self-concept & Low & $54-73$ & 33 & 14 \\
& Medium & $74-89$ & 183 & 76 \\
\multirow{3}{*}{ Basic psychological need satisfaction } & High & $90-96$ & 24 & 10 \\
& Low & $27-45$ & 31 & 13 \\
& Medium & $46-58$ & 194 & 81 \\
Teaching motivation & High & $59-63$ & 15 & 6 \\
& Low & $35-40$ & 47 & 20 \\
& Medium & $41-48$ & 152 & 63 \\
\hline
\end{tabular}

\section{Structural Model}

The following tests must be carried out to conduct analysis using structural equation modelling (SEM) and obtain assumptions that must be met, including: (1) The number of samples in testing with SEM consisting of at least 5 constructs is 150 . The sample used in this study was 241 respondents, so they have met the minimum number of samples for testing; (2) SEM analysis assumes that data is normally distributed both unvariate and multivariate. The value of c.r is in the range of -2.58 to 2.58 $(-2.58<\mathrm{CR}<2.58)$, so the assumption of data normality required by SEM analysis is fulfilled; (3) The next assumption is that there are no outliers both univariate or multivariate, if there are no descriptive statistics values that indicate a $Z$ value higher than 3.0. All data in this study have $z$ values scored in intervals of -3 to 3 , so the research data do not contain univariate outliers; (4) The next assumption to be tested is the absence of multicollinearity, with the determinant sample covariance matrix value in the research being quite large.

We can see the following structural model equation to know the correlation between the studied variables. This equation is designed to state the causality correlation between the constructs. In this part, the equation between variables of school climate, self-concept, basic psychological need satisfaction, and teaching motivation. The structural model tested in this study can be seen in the Figure 1. 


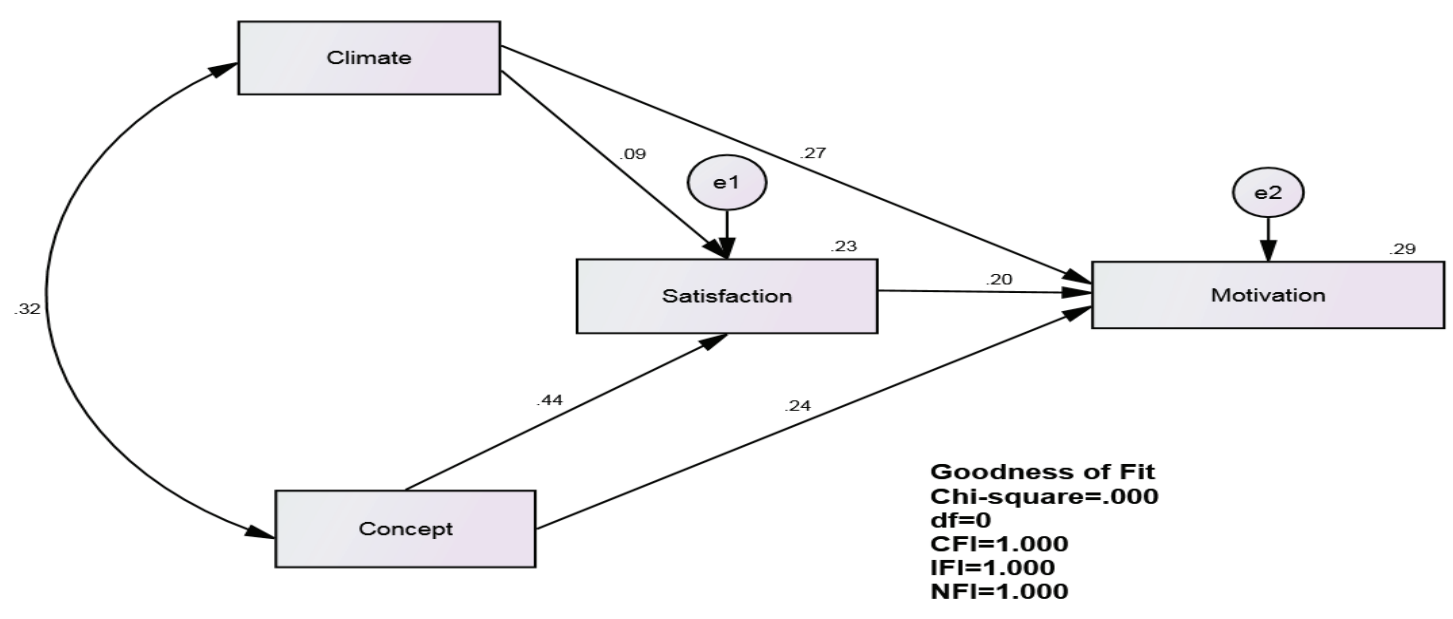

Figure 1. Structural Models

Based on Figure 1, it is known that there are four criteria for goodness of fit that meet the recommended critical limits, namely: Chisquare $=.000$ (the smaller the better); CFI $=$ 1.000 (critical value $>.95)$; NFI $=1.000$ (critical value $>.90)$; IFI $=1.000$ (critical value $>.90)$. Based on these data, it can be concluded that the research model used in this study is goodfit, because there is at least one criterion that meets the criteria of goodness of fit. Thus, this structural model can be used to test direct or indirect effects.

\section{Direct and Indirect Influence}

Based on the results of calculations through Structural Equation Modelling analysis, this research model can be accepted. The results of the analysis of direct and indirect effects can be seen in Table 3 .
It is known that there are five coefficients of direct influence and two coefficients of indirect effect. The direct effects produced were (1) the influence of the school climate with teaching motivation with a coefficient of .267 and p-value $(<.05)$ is significant $(\mathrm{h} 1)$; (2) the effect of self-concept on teaching motivation with a coefficient of .245 and $\mathrm{p}$-value $(<.05)$ is significant (h2); (3) the influence of school climate with basic psychological need satisfaction with a coefficient of .089 and p-value $(>.05)$ is not significant (h3), (4) the influence of self-concept with basic psychological need satisfaction with a coefficient of .444 and p-value $(<.05)$ is significant (h4); (5) the influence basic psychological need satisfaction with teaching motivation with a coefficient of .204 and $\mathrm{p}$-value $(<.05)$ is significant $(\mathrm{h} 5)$. The indirect effects produced are (1) the influence of the

Table 3. Direct and Indirect Influence

\begin{tabular}{ccccccc}
\hline Hypothesis & \multicolumn{3}{c}{ Influence } & SRW (E) & S.E. & p \\
\hline 1 & Climate & $\rightarrow$ & Motivation & .267 & .057 & .000 \\
2 & Concept & $\rightarrow$ & Motivation & .245 & .034 & .000 \\
3 & Climate & $\rightarrow$ & Satisfaction & .089 & .093 & .138 \\
4 & Concept & $\rightarrow$ & Satisfaction & .444 & .051 & .000 \\
5 & Satisfaction & $\rightarrow$ & Motivation & .204 & .039 & .001 \\
6 & Climate $\rightarrow$ Satisfaction $\rightarrow$ Motivation & .285 & .019 & .346 \\
7 & \multicolumn{2}{c}{ Concept $\rightarrow$ Satisfaction $\rightarrow$ Motivation } & .335 & .020 & .000 \\
\hline
\end{tabular}

Note: Climate: School climate; Concept: Self-concept; Satisfaction: Basic psychological needs satisfaction; motivation: teaching motivation; S.E: Scalar Estimates p: probability; SRW(E): Standardized Regression Weights (Estimate) 
school climate affecting teaching motivation by mediating the satisfaction of basic psychological needs with a coefficient of .285 and p-value ( $>$ .05 ) is not significant (h6); (2) the influence of self-concept influences teaching motivation by mediating the satisfaction of basic psychological needs with a coefficient of .335 and p-value (< $.05)$ is significant (h7).

\section{Discussion}

Based on the results of data analysis, school climate provides a direct and significant influence on teacher motivation to support the first hypothesis. Although the results of the analysis of school climate data only contribute sufficiently to teaching motivation, of course the school climate has a major role for teachers in shaping their teaching motivation. The findings of this study indicate the condition that environmental factors support and play an important role in developing teacher teaching motivation. School environment and teacher interpersonal relationships have emerged to be important factors that have the potential to influence teacher motivation (Kocabas, 2009, Wei, 2012). Deci \& Ryan (1985) stated in a school setting, motivated teachers can condition and manage class well. Furthermore, based on the theory of self-determination that support from schools perceived by teachers can meet the needs of competence and the needs of interrelationships that can potentially increase the intrinsic motivation of teachers in teaching. In addition, the findings of this study support the statement of Wei (2012) that school climate as an external factor has a strong influence on teacher motivation, and teachers who understand the importance of school climate will have implications for education (Werang, 2018).

However, on the other hand, based on the results of data analysis, the school climate does not influence the basic psychological needs satisfaction of teachers when carrying out teaching and learning activities in schools, so it does not support the third hypothesis. Theoretically, that according to Deci \& Ryan (2000) the basic psychological needs theory emphasizes that individuals tend to be involved in an integrative process that is a process that is intrinsically motivated when the environment facilitates the individual's basic psychological needs themselves. In other words, individual motivation will increase when the basic psychological needs are satisfied. The theoretical research findings also reinforce the statement that not all behaviors are intrinsically motivated, but some behaviors are motivated by having the support of environmental and contextual factors. These contextual factors influence the extent to which behavior is internalized (Ryan \& Deci, 2000a).

Internalization behavior felt by one teacher is very different, so the support from the school that is felt by the teacher does not all support the fulfillment of the three basic psychological needs. The teacher feels support from the school is only to meet the need for competence, on the other hand the other teacher feels that the support from the school is only to fulfill the need to establish good communication with colleagues, even though the school climate has the potential to increase teacher satisfaction and retention at work, which is a primary concern in education (Boe, Cook, \& Sunderland, 2008; Kaiser, 2011).

The findings of the next research are, selfconcept gives a direct and significant influence on teaching motivation, thus supporting the second hypothesis, even though it only contributes sufficiently in teaching motivation. This certainly gives meaning that the higher the teacher's selfconcept, the higher the motivation to teach teachers in school. The influence of self-concept on teaching motivation is supported based on the theory of self-determination proposed by Deci \& Ryan (1985), that self-concept or the role of competence is a factor of autonomous motivation. Several research findings show that self-concept significantly determines motivation (Marsh, Craven, \& Debus, in Ahmed \& Bruinsma, 2006). The findings of this study are also corroborated by Deci \& Ryan's (1995) statements about selfdetermination theory which propose that the term self-competence similar to self-concept is an important antecedent of motivation to be independent (autonomous motivation).

Research studies in cross-cultural, both Asian and European cultures, show the results of a significant correlation between self-concept and motivation to be independent (Ahmed \& Bruinsma, 2006), so that this can support the findings of this study conducted on culture in Indonesia. However, the fundamental difference is in the teaching process of teachers who are still dominant by the teacher. Although the 
teaching process is dominated by the teacher, Yeung, Craven, \& Kaur (2014) in their research found that teachers who have good self-concepts in teaching can combine various teaching approaches, so that teachers have confidence that can increase their motivation to teach.

Basic psychological needs satisfaction is an important factor in developing positive selfperception. The concept of satisfaction of needs has provided theoretical support to direct the relationship between satisfaction of needs and physical self-concept (Deci \& Ryan, 1995). Thus, satisfaction of the needs for autonomy, competence, and the need for interconnectedness are associated with high physical self-concept. This statement supports the results of this study that self-concept has a direct influence on the satisfaction of basic psychological needs, and also supports the fourth hypothesis. Garn, McCaughtry, Mastin, Shen, \& Fahlman (2012) states that satisfaction of needs becomes a strong framework for investigating specific selfconcepts. Teachers who have a low self-concept prefer the traditional approach, and the low selfconcept that the teacher has creates a relative obstacle in building personal relationships. Whereas teachers who have high self-concepts tend to spend less time on routine activities that do not use the mind, such as distributing books, collecting student work, taking notes, registering, etc. (Burns, 1993).

Psychological basic needs are the most common needs marked by individual differences in satisfying those needs. In addition, basic needs provide an understanding of various social environments and forces in influencing motivation (Deci \& Ryan, 2000). Therefore, satisfaction of an individual's basic needs is an important context, and must be satisfied to experience motivational behavior in self-determination. Satisfaction of needs is satisfaction because the fulfillment of basic psychological needs for humans and intake for the development of motivation that provides energy, and directs individual behavior (Deci \& Ryan, 2000). Needs satisfaction studies relate to the basic needs of psychological competence or achievement, autonomy and control or power, and relatedness or affiliation (Woolfolk, 2009).

The results of the research of Hanfstingl, Andreitz, Muller, \& Thomas (2010) who investigated the investigation of the relevance of basic psychological needs and personality factors to the intrinsic teaching motivation of teachers, showed the results that personality factors can predict teacher teaching motivation, and satisfaction of basic needs is positively correlated with teaching motivation intrinsic in school. This is consistent with Ryan \& Deci's (2000b) explanation that the support and satisfaction of basic needs is important for developing intrinsic motivation. Based on this description, in line with the results of this study that the basic psychological needs satisfaction has a direct and significant influence on teaching motivation, and also supports the second hypothesis. This means that the basic psychological needs satisfaction has a significant influence on the motivation of teaching teachers who teach in disadvantaged areas, and the satisfaction of basic psychological needs influences the quality of positive teacher behavior in schools, which can be seen from their teaching motivation.

Based on the results of data analysis, specifically about the role of basic psychological needs satisfaction as a mediator, that basic psychological needs satisfaction does not mediate the role of the school climate on teaching motivation. This means that basic psychological needs satisfaction does not become a strong intermediate variable between the school climate and teaching motivation, so it does not support the sixth hypothesis. Based on the previous explanation, the school climate has a direct influence on teaching motivation, but the school climate does not have a significant role in satisfying the basic psychological needs. This is very contrary to the study described by Gagne \& Deci (2005) that the basic psychological needs satisfaction is a nutriment for the development of self-determinant motivation.

The basic psychological needs of an individual consisting of a sense of competence, autonomy and connectedness are fundamental and universal needs for individual happiness. The experience of satisfying psychological needs of teachers that occur is influenced by better or worse conditions related to work, and how much experience of satisfaction of psychological needs in influencing teacher motivation. For example, teaching and learning activities tend to be done half-heartedly, without integrity, and lack of responsibility to achieve quality results (Sariwulan, Agung, Sudrajat, \& Atmadiredja, 
2019). In line with this, Niemic \& Ryan (2009) explain that internal factors that affect intrinsic motivation are satisfaction of basic psychological needs, namely satisfaction of autonomous needs that refer to the experience of will behavior and self-reflection, and satisfaction of competency needs that refer to behavioral effectiveness, and can sustain intrinsic motivation.

Basic psychological needs satisfaction mediates the role of the self-concept of teaching motivation, and supports the seventh hypothesis. This means that the basic psychological needs satisfaction is a powerful construct in mediating self-concept with the teaching motivation of teachers. Support theoretically states that individual motivation is related to personality development and self-regulation (Ryan \& Deci, 2000b). Self-regulation refers to the way individuals control and direct their own actions (Taylor, Peplau, \& Sears, 2009). Meanwhile, an important component in personality development that will affect individual behavior is related to self-concept (Hurlock, 2011).

According to Judge, Erez, \& Bono (1998) stated that positive self-concept as a source of work motivation in the context of work. If a teacher is confident in himself both in terms of ability and others, then the potential possessed can run optimally, so that the teacher is able to increase motivation to teach at school. The self-concept is an internal factor of the teacher as a basic strength, which energizes and directs individual behavior which includes: the individual's confidence in himself, seeing his self-image and self-esteem, and his response to others in relation to his duties as a teacher.

\section{CONCLUSION}

Attention to teachers who teach in disadvantaged areas shows that the school climate and teacher's self-concept differently provide an important role in teaching motivation mediated by basic psychological needs satisfaction. School climate as an external factor shows the conditions that the school environment and interpersonal relationships support and play an important role in developing teacher teaching motivation. In addition, support for a good school climate can be seen from the school setting, where motivated teachers can condition and manage their classes well. In addition to external factors, self-concept as internal support can be a source of motivation when individuals are motivated to maintain and enhance self-internalization, and basic psychological needs satisfaction also plays an important role in supporting teacher teaching motivation. The teacher has the basic psychological needs satisfaction of autonomy when the teacher feels allowed to express ideas and opinions, authentic self-capacity arises, and the teacher is free to do things the teacher's own way. Basic psychological needs satisfaction of competency needs involves feeling effective in individual actions or activities. Basic psychological needs satisfaction of relatedness refers to feelings of belonging to others, and to care for and care for others. The implication of this research is the need for programs to develop teacher motivation in disadvantaged areas by optimizing and considering school climate, self-concept, and basic psychological needs satisfaction as influential factors.

\section{ACKNOWLEDGMENT}

The authors would like to thank the financial support provided by Ministry of Research, Technology, and Higher Education of Indonesia through Penelitian Disertasi Doktor (PDD) 2018.

\section{REFERENCES}

Abeles, L. R. (2013). Teacher absenteeism: The school factor. Retrieved from: https:// studylib.net/.

Ahmed, W. \& Bruinsma, M. (2006). A structural model of self-concept, autonomous motivation and academic performance in cross-cultural perspective. Electronic Journal of Research in Educational Psychology, 4(3), 551-575. doi:10.25115/ ejrep.v4i10.1214.

Boe, E. E., Cook, L. H., \& Sunderland, R. J. (2008). Teacher turnover: Examining exit attrition, teaching area transfer, and school migration. Exceptional Children, 75(1), 7-31. doi:10.1177/001440290807500101.

Burns, R. B. (1993). Konsep diri: Teori, pengukuran, perkembangan dan perilaku. (Trans. by Eddy). Jakarta, Indonesia: Arcan. 
Deci, E. L., \& Ryan, R. M. (1985). Intrinsic motivation and self.determination in human behavior. New York, NY: Plenum Press.

Deci, E. L., \& Ryan, R. M. (1995). Human autonomy: The basis for true self-esteem. In M. Kernis (Ed.), Efficacy, agency, and self-esteem (pp. 31-49). New York, NY: Plenum Publishing Co.

Deci, E. L., \& Ryan, R. M. (2000). The 'what' and 'why' of goal pursuits: Human needs and the self-determination of behavior. Psychological Inquiry, 11(4), 227-268. doi:10.1207/S15327965PLI1104 01.

Deci, E. L., Ryan, R. M., Gagne, M., Leone, D., Usunov, J., \& Kornazheva, B. P. (2001). Need satisfaction, motivation, and wellbeing in the work organizations of a former Eastern Bloc Country. Personality and Social Psychology Bulletin, 27(8), 930942. doi:10.1177/0146167201278002.

Dirjen Cipta Karya. (2012). Identifikasi lokasi desa terpencil desa tertinggal, dan pulau-pulau kecil. Retrieved from https:// ciptakarya.pu.go.id/.

Gagne, M. (2003). The role of autonomy support and autonomy orientation in prosocial behavior engagement. Motivation and Emotion, 27(3), 199-223. doi:10.1023/A:1025007614869.

Gagne, M. \& Deci, E. L. (2005). Selfdetermination theory and work motivation. Journal of Organizational Behavior, 26(4), 331-362. doi:10.1002/job.322.

Garn, A. C., McCaughtry, N., Mastin, J., Shen, B., \& Fahlman, M. (2012). A basic needs theory investigation of adolescents' physical self-concept and global selfesteem. International Journal of Sport and Exercise Psychology, 10(4), 314-328. doi:10.1080/1612197X.2012.705521.

Hanfstingl, B., Andreitz, I., Muller, F. H. \& Thomas, A. (2010). Are self-regulation and self-control mediators between psychological basic needs and intrinsic teacher motivation? Journal for Educational Research Online, 2(2), 5571.

Hartini, Y. (2012). Motivasi dan kinerja guru sekolah dasar desa terpencil di Kabupaten Banjar (Master Thesis, Universitas Negeri Yogyakarta). Retrieved from https:// eprints.uny.ac.id/.

Hoy, W. K., Smith, P. A., \& Sweetland, S. R. (2002). The development of the organizational climate index for high schools: Its measure and relationship to faculty trust. The High School Journal, 86(2), 38-49. doi:10.1353/hsj.2002.0023.

Hurlock, E. B. (2011). Psikologi perkembangan: Suatu pendekatan sepanjang rentang kehidupan (Trans. by Istiwidayati). Jakarta, Indonesia: Erlangga.

International Test Commission. (2017). ITC guidelines for translating and adapting tests $\left(2^{\text {nd }} e d\right)$. International Journal of Testing, 18(2), 101-134. doi:10.1080/153 05058.2017 .1398166 .

Judge, T. A., Erez, A., \& Bono, J. E. (1998). The power of being positive: The relationship between positive self-concept and job performance. Human Performance, 11(2-3), 167-187. doi:10.1207/ s15327043hup1102\&3_4.

Kaiser, A. (2011). Beginning teacher attrition and mobility: Results from the first through third waves of the 2007-08 beginning teacher longitudinal study (NCES 2011318). Retrieved from U.S. Department of Education, National Center for Education Statistics website: https:nces.ed.gov/ pubsearch/.

Kocabas, I. (2009). The effects of sources of motivation on teachers' motivation levels. Education, 129(4), 724-733.

Leonard, N. H., Beauvais, L. L., \& Scholl, R. W. (1999). Work motivation: The incorporation of self-concept-based 
processes. Human Relations, 52(8), 969998. doi:10.1177/001872679905200801

Mansfield, C., Wosnitza, M., \& Beltman, S. (2012). Goals for teaching: Towards a framework for examining motivation of graduating teachers. Australian Journal of Educational \& Developmental Psychology, 12, 21-34.

McKenzie, P., Nugroho, D., Ozolins, C., McMillam, J., \& Sumarto, S. (2014). Study on teacher absenteeism in Indonesia 2014. Jakarta, Indonesia: Education Sector Analytical and Capacity Development Partnership (ACDP).

Niemic, C. P. \& Ryan, R. M. (2009). Autonomy, competence, and relatedness in the classroom: Applying self-determination theory to educational practice. Theory and Research in Education, 7(2), 133-144. doi:10.1177/1477878509104318.

Paramitha, P. P. (2012). Resiliensi guru di sekolah terpencil. Jurnal Psikologi Pendidikan dan Perkembangan, 1(02), 1-6.

Pretorius, S., \& De Villiers, E. (2009). Educator's perception of school climate and health in selected primary school. South African Journal of Education, 29(1), 33-52. doi:10.1590/S0256-01002009000100003.

Putri, A. I., Destio, F. G., \& Rahmayanti, S. F. (2017, 12 September). Guru garis depan, membangun Indonesia dari pinggiran. Retrieved from https://www.kemdikbud. go.id/.

Reeve, J., \& Su, Y.-L. (2014). Teacher motivation. In M. Gagne' (Ed.), The Oxford handbook of workplace motivation (Chpt. 21, pp. 349-362). New York, NY: Oxford University Press.

Richardson, P. W., Watt, H. M. G., \& Karabenick, S. A. (2014). Teacher motivation matters: An introduction. In P. W. Richardson, S. A. Karabenick, \& H. M. G. Watt (Eds.), Teacher motivation: Theory and practice (pp. xiii-xxii). New York, NY: Routledge.
Roth, G., Assor, A., Kanat-Maymon, Y. \& Kaplan, H. (2007). Autonomous motivation for teaching: How self-determined teaching may lead to self-determined learning. Journal of Educational Psychology, 99(4), 761-774. doi:10.1037/00220663.99.4.761.

Ryan, R. M., \& Connell, J. P. (1989). Perceived locus of causality and internalization: Examining reasons for acting in 2 domains. Journal of Personality and Social Psychology, 57(5), 749-761. doi:10.1037/0022-3514.57.5.749.

Ryan, R. M., \& Deci, E. L. (2000a). Intrinsic and extrinsic motivations: Classic definitions and new directions. Contemporary Educational Psychology, 25(1), 54-67. doi:10.1006/ceps.1999.1020.

Ryan, R. M., \& Deci, E. L. (2000b). Selfdetermination theory and the facilitation of intrinsic motivation, social development, and well-being. American Psychologist, 55(1), 68-78. doi:10.1037/0003066X.55.1.68.

Salifu, I., \& Agbenyega, J. S. (2013). Viewing teacher motivation in the Ghana Education Service through a postcolonial lens. Current Issues in Education, 16(3), 1-12.

Sariwulan, T., Agung, I., Sudrajat, U., \& Atmadiredja, G. (2019). The influence of job expectation, job satisfaction, and government policy towards the work stress, job enthusiasm and continuance commitment of the honorarium teacher. Cakrawala Pendidikan, 38(2), 305-319. doi:10.21831/cp.v38i2.24380.

Setiyowati, A. J., Pali, M., Wiyono, B. B., \& Triyono, T. (2019). Structural model of counseling competence. Cakrawala Pendidikan, 38(1), 45-62. doi:10.21831/ cp.v38i1.21509.

Sofiah, S. (2016). Analisis sebaran guru dikdasmen di wilayah $3 T$ (Tinjauan sekolah menengah pertama). Jakarta, 
Indonesia: Pusat Data dan Statistik Pendidikan dan Kebudayaan.

Taylor, S. E., Peplau, L. A., \& Sears, D. O. (2009). Psikologi sosial (edisi ke dua belas). (Trans. by Tri Wibowo B. S.). Jakarta, Indonesia: Kencana Prenada Media Group.

Villa, A., \& Calvete, E. (2001). Development of the teacher self-concept evaluation scale and its relation to burnout. Studies in Educational Evaluation, 27(3), 239-255. doi:10.1016/S0191-491X(01)00028-1.

Wei, Y. (2012). A hierarchical approach to examine personal and school effect on teacher motivation. (Doctoral Dissertation, The Ohio State University). Retrieved from https://etd.ohiolink.edu.
Werang, B. (2018). The effect of workload, individual characteristics, and school climate on teachers' emotional exhaustion in elementary schools of Papua. Cakrawala Pendidikan, 37(3), 457-469. doi:10.21831/cp.v38i3.20635.

Woolfolk, A. (2009). Educational psychology active learning edition. (Trans by Helly P. S.). Yogyakarta, Indonesia: Pustaka Pelajar.

Yeung, A. S., Craven, R. G., \& Kaur, G. (2014). Teachers' self-concept and valuing of learning: Relations with teaching approaches and beliefs about students. Asia-Pacific Journal of Teacher Education, 42(3), 305-320. doi:10.1080/1 359866X.2014.905670 